\title{
The Effectiveness of Total Physical Response (TPR) on Teaching English to Young Learners
}

\author{
Rong Xie \\ School of International Education, Tongren Preschool Education College, Tongren, Guizhou, China
}

\begin{abstract}
This article through two teachers' cases, namely, observation of two teachers' classes and interview with them, interview with their students and their students' parents, attempts to investigate the effectiveness of TPR as a classroom technique with young learners and to explore how teachers use TPR and to identify some of the challenges of using it in practice. All the findings are discussed referring back to the relevant literature review and context. The findings of observation indicate that the TPR technique is a good way on the basis of games, role-play, storytelling and pair works with the physical actions. It also finds some potential factors that contribute to TPR's challenges in practice, such as the use of traditional method, training constraints, students' low English proficiency, the lack of authentic environment and exam-oriented assessment. The findings from the various angles obtained seem to be very similar to those reported earlier by literature review. This study also makes a contribution to the existing literature in terms of the providing insights into the attitudes toward English education for parents or students, and the lack of parents' supervision to some extent that they have influenced on the TPR. Importantly, through a systemic introduction of TPR in this study, it is useful to help future teachers to implement TPR methods into their young learner teaching. The results of this study can also help me to reflect on my own teaching approaches and support other teachers working in my college.
\end{abstract}

Index Terms - Total Physical Response (TPR), young learner, English

\section{INTRODUCTION}

\section{A. Macro Context-TEYL in China}

The leaders of the People's Republic of China proposed that universal English proficiency is deemed a significant element of the development strategy during the country's global competitiveness. The educational authorities have implemented a range of reforms (Ministry of Education, 2011, p. 1). The basic requirements of curriculum for primary school English are categorized in below:

a. To provoke pupils' interests, build up self-confidence and positive attitude towards learning another language.

b. To develop the pupil's initial ability to use English in daily communicating.

c. To lay a good basis for spoken English and further study.

d. To develop children's potentials of language intelligence, cognition intelligence, interpersonal intelligence, musical and sports intelligence as much as possible.

e. To fulfil English teaching activities in accordance with the personal characteristics of children.

f. Young learners need to be provided with adequate opportunities to practice L2. The teacher should encourage them to communicate their ideas or thoughts in a positive learning environment. (Ministry of Education, 2011; Wang, 2002; cited in Xie, 2017, p. 3).

The specific teaching requirement is designed into nine proficiency-based levels. The primary period was designed into two levels. Namely, the pupils from Grade 3 to Grade 4 are required to master level 1 proficiency, while the pupils from Grade 5 to Grade 6 are required to master level 2 proficiency. The following provides the framework of the curriculum both level 1 and level 2: 


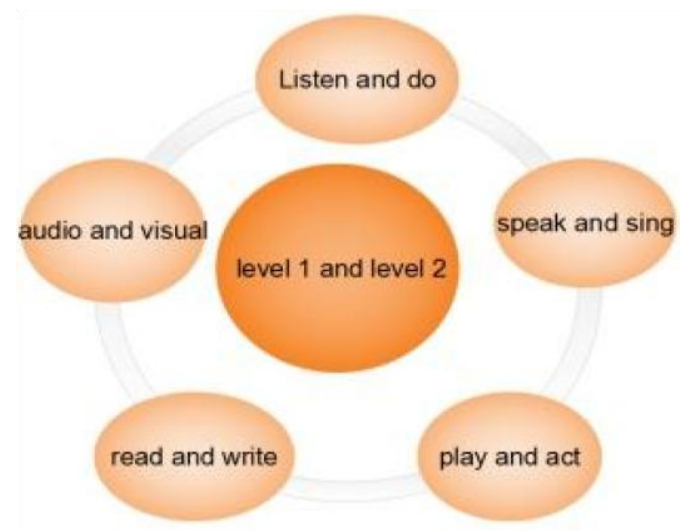

Figure 1 The framework of the curriculum both level 1 and level 2

(Wang, 2002, p. 100)

From the fig 1 it can be seen that although the basic requirement does not enforce any methods to teach young learners, it clearly reflects an activities-based approach, via listening, speaking, singing, playing, acting, and doing to provide opportunities to experience the language. Children are required learning by doing. The learning procedure is expected to be a happy and enjoyable experience. The purpose of assessment is to enhance pupils' overall development, formative assessment and portfolio are expected to be used as the method of evaluating their English achievement. Hence, under the context of advocating English instruction reforms, communicative language teaching (CLT) is currently considered as the most popular approach for teaching young learners. CLT in China as an imported approach was introduced in foreign language teaching since the late 1980s (cited in Hu, 2008, p. 93-105). Just as Asher (1972) mentioned, TPR is regarded as one of the most important techniques in CLT, it seems that the author has the same viewpoint with him, because many features in CLT also apply to the features of TPR, as a technique within a more general communicative approach. Despite the national curriculum is to support teaching in terms of the rationale of CLT/TPR. However, CLT/TPR are seriously influenced by a range of factors in her context, in some cases, it does not really reflect the goal of learning English as expressed in the curriculum documentation.

\section{B. Micro Context-TEYL in Her College}

\section{The use of TPR}

The teachers are required to use government-approved books named Primary English. The contents are based upon the TPR activities (e.g., pictures, flash cards, songs, storytelling, role-plays and rhymes). From the contents of government-approved books, we can see the extent to which it matches the framework of the curriculum both level 1 and level 2. According to the daily talking with her colleagues, they often adopt an activities-based to teach young learners, such as they conduct TPR songs as warming up at the beginning of the class. It can be found that TPR can effectively provide a positive learning environment for young learners. It can also cultivate children's interests to learn English. Her colleagues share the same experience with them. But they are required to complete all the contents within 18 weeks which have two classes (40 minutes per class) a week. Most of the time the author is eager to implement TPR activities, while it is impeded owing to the constraint of time. Sometimes, they also implement Grammar-translation Methods and Audio-lingual methods to teach young learners due to students' low English proficiency. Because TPR emphasizes on students' communicative competence, it is required to have a good foundation in speaking aspect. Hence, for traditional approaches, it seems to be as a supplementary method. The paper-pencil tests are often adopted which is designed by a local administrator, on the basis of assessing the ability of students' reading, listening and writing at the end of each semester.

2. The background of her College

Guizhou province is located in the Southwest of China, compared with the coastal areas, the aspects of economy and education still exist a big gap. Agriculture is regarded as the principal occupation of almost all inhabitants of this region. Farmers spend a great number of time or energy cultivating crops, but they obtain extremely low incomes. Therefore, many farmers are willing to work in coastal areas in order to earn higher incomes to support the expenditure of their families. Their children who have been left behind in rural areas lead to without the guidance, love and nurturing of parents. The College where she works is named Tongren Preschool Education College in Guizhou province. Additionally, she also undertake the task of teaching English to young learners in a private primary school, which belongs to a supporting programme of her institution owing to the serious shortage of teachers. Therefore, some teachers in her college are sent to teach in this private primary school. Some others are from college students who have just graduated. According to the requirement of this college, these novices are obliged to take part in pre-service training before he or she starts work. The content of the training is only referred to the knowledge of pedagogics and psychologies, it is not referred to teacher's professional knowledge at all. Meanwhile, the two kinds of teachers have mentioned in above who have not received any training courses regarding TPR or teaching English to young learners. 
Additionally, the students for this college, most of them are left-behind children, through her observation in the past, these pupils are always lonely and reticence because they are short of their parents' love. The other teachers have also shared the same point of view. Hence, the implementation of TPR in the classroom may be influenced in the author's context. The next section will be elaborately argued on how the curriculum fits into the CLT/TPR, and the factors that contribute to CLT /TPR difficulties.

\section{LITERATURE REVIEW}

\section{A. The Features of CLT}

Communicative Language Teaching (CLT) is an approach to the goal of language teaching which is using language for social interaction with other people to develop as communicative language competence (Butler, 2011). Similarly, Littlewood (2007) states that the function of language is seen as one of the most important features of CLT (Wilkins (1972; cited in Butler, 2011). Savignon (2003) concludes that five main features should be characterized in the CLT.

1. The target language is emphasized on learning to communicate.

2. Authentic texts are introduced into learning situations.

3. Focusing not only on language but also on the acquisition process itself.

4. Making good use of learner's personal experiences.

5. Creating real communication scenario in the classroom (p. 223-249).

According to their point of view, it seems that the function of language means the use of target language in real communication scenario. This so-called learner's personal experience means that it is related to learn by doing just like the curriculum mentioned. Consequently, learning activities are selected according to the use of authentic resource rather than the merely mechanical practice of language patterns. While over-learning and mechanical memorization are stressed in Grammar-translation Methods (GTM) and Audio-lingual methods (ALM) (Wedell and Malderez, 2013). Language instruction in GTM is generally regarded as the delivery of knowledge rather than the development of communicative ability ( $\mathrm{Hu}, 2005$, p. 597). On the contrary, language whole classroom activities in CLT are learner-centred, because the learners are actively involved in the learning process. The teacher is seen as a facilitator of students' learning and a manager of classroom activities. The learner is regarded as a negotiator, communicator and imitator. Teacher-learner relationship is an interactive, harmonious relationship. The communicative language teaching stresses the learners' cognitive abilities and operational capabilities, this viewpoint is in accordance with the requirement of the curriculum in China - learning by doing. In contrast, GTM \& ALM emphasize on the teacher who used the L1 to manage learning in the classroom. Additionally, advantages of CLT are greatly to provoke the learner's interest to learn English as a pleasure, the viewpoint of this is consistent with the goals of the curriculum to provoke pupils' interests in context.

To sum up, the goals of CLT mainly stress the form of communicating in the conversation (wedell and Malderez, 2013). In some sense, the curriculum of primary English in China has matched the features of CLT. Nonetheless, CLT is not really presented in practice due to various factors. For example, achievements of assessing young learners are mainly based on the examination-oriented assessment, this is seen as typical feature of GTM. While CLT suggests that the teachers are expected to change their way of assessing young learners' achievement into use formative assessment, portfolio and alternative assessment. About the description of assessing young learners in curriculum is consistent with the feature of CLT. CLT is considered as an effective approach to meet the needs of young learners. But, CLT is very extensive, so I decide to concentrate on a specific kind of method, and I choose Total Physical Response (TPR) which is developed by James Asher to do the study. To some extent, he has clearly identified its effectiveness in teaching English to young learners.

\section{B. The Features of TPR}

TPR is proposed by American psychologist James Asher at the end of the 1960s which involves having learners listen to a command in a foreign language and immediately respond with the appropriate physical action (Asher, 1972). Richards and Rogers (2001) reveal the TPR is a language instruction method built around coordination of speech and action. From the description in above, it can be seen that TPR emphasizes on listening, speaking and doing, these are in accordance with the goals of both level 1 and level 2. The method is intended to simulate children to acquire a second language spontaneously. According to Asher's thoughts, once a foundation in listening comprehension has been established, the development of speech would be naturally occurring without any efforts (cited in Ai Harrasi, 2014, p. 36). Asher confirms that L2/foreign language learning is parallel to L1 learning and reflects similar naturalistic processes (Asher, 1977).

1. Bilateral

It is authenticated by many scientists that language activities are implemented in the left brain, and physical actions are coordinated by the right brain. Using TPR in language teaching can effectively assist children to work both parts of the brain (Asher, 1977). It seems to be a good way to build up physical and mental development of children. Curriculum for young learners also highlights the overall development of children.

2. Using interactive activities 
Asher (1972) claims that TPR activities play an interactive effectiveness in the authentic classroom between teacher-student and student-student. Just as Savignon (2003) emphasizes that CLT is based on the social interaction with other people. Both Vygotsky (1962) and Bruner (1967) defend that the language and learning development can be possible thanks to the social interaction with other children or adults ( Porta, 2013). Despite that the national curriculum does not enforce any specific method for teaching, they clearly reflect an activity based on interaction, for instance, group work, role-play and guessing games.

3. Lowering the affective filter

One of the significant features of TPR can effectively low the affective filter to promote the learning process. Learners' anxiety may be lowered to that of a more natural setting so that they do not feel threatened in a language classroom (Asher, 1981; cited in AI Harrasi, 2014, p.37), while CLT also emphasizes on the experience of language in a stress-free environment.

4. Promoting the motivation

TPR constructed a motivating environment by encouraging learners to participate and involve him/herself in action, which increases their enthusiasm as they feel free to move around. TPR learners experience the language in a relaxed and comfortable atmosphere (Larsen-Freeman, 2000).

5. Building self-esteem and confidence

Asher (1977) suggests that TPR builds learners' self-esteem and confidence. When learners respond commands through the motor movement, students feel secure because actions are easy to follow and understand, they have enough confidence and ability to communicate with their peers out of any obstacles (Asher, 1972). To some extent that they are given more encouragement and confidence to participate freely out of feeling disappointed, even if they have low English proficiency (Celestino, 1993). In a word, it seems that TPR makes everyone feel positive and able to trust their ability. These viewpoints are consistent with the curriculum's requirement, for example, to provoke pupils' interests, to build up pupils' self-confidence and a positive attitude towards learning English.

\section{Comparison between TPR and GTM/ALM}

TABLE 1

THE FEATURES OF TPR

\begin{tabular}{|c|c|}
\hline Item & TPR \\
\hline Features & $\begin{array}{l}\text { Emphasis on interaction /function/ communication/practice/application } \\
\text { Emphasis on stress-free, learner-centred, authentic text/scenario, } \\
\text { subconscious /implicit/informal process } \\
\text { Lowering the affective filter, promoting the motivation, building self-esteem } \\
\text { and confidence, learning is an internalization. }\end{array}$ \\
\hline Roles & Emphasis on teacher is facilitator/model, student is negotiator/ communicator/imitator \\
\hline Assessment & Formative/portfolio assessment \\
\hline
\end{tabular}

TABLE 2

THE FEATURES OF GTM/ALM

\begin{tabular}{|c|c|}
\hline Item & GTM/ALM \\
\hline Features & Emphasis on overuse/memorization/translation \\
\hline & Teacher-centred, conscious/explicit/formal process, memorization, \\
\hline Roles & Teacher is controller/translator, student is follower \\
\hline Assessment & Examination-oriented \\
\hline
\end{tabular}

Compared to table 1 and table 2, it can be seen that the features of TPR are different from the features of GTM/ALM, because TPR emphasizes the process of subconscious/implicit/informal to acquire the language. It also stresses that the interaction/function/communication of language acquisition is under the stress-free environment via authentic text /scenario. The benefits of TPR can be identified to lower the affective filter, promote the motivation, and build self-esteem and confidence. The achievement of learners' English proficiency is expected to apply to the formative/portfolio assessment. On the contrary, the overuse/memorization/ translation and exam-oriented assessment system are highlighted in GTM/ALM. Hence, the requirement of the curriculum matches the features of TPR.

\section{Theoretical Foundation of TPR}

\section{Second language acquisition}

Piaget points out that children learn language through the muscle control or experience with objects in their environment (cited in Cameron, 2001, p. 4). TPR instruction is via the student's verbal and non-verbal responses, such as physical movement to look, to eat, to run, to reach for something, to laugh or to cry are all medium through which young learner can decode the language. Nevertheless, Asher's view acquisition language through experience is similar 
to Piaget's. Vygotsky (1978) claims that the child as social, there is a potential distance between the actual developmental level as determined by independent problem solving, learning as internalization, child's foreign language learning depends on what they experience (cited in Cameron, 2001, p. 5). Therefore, one of the major features in TPR activities is based on problem-solving via pair work, group work with peers or teachers' help (Asher, 1972)

Krashen (1983) puts forward that acquisition input hypothesis is a subconscious, implicit, informal process, learners are not usually aware of the fact that they are learning language, but only aware of the fact that they are using the language for communication. Meanwhile, he also claims that language learning is a conscious, explicit, formal process. A comparable result with Ellis (1999) argues that SLA is mainly via implicit language learning. The author supports their viewpoints, it seems that GTM highlights a kind of consciousness, explicit, formal teaching process (Wedell and Malderez, 2013), such as students are required to sit in their fixed seats and keep a good discipline. As far as I am concerned, TPR belongs to the process of language acquisition due to its implicit teaching. Additionally, Krashen (1983, p.66) puts forward that another hypothesis is comprehensible input, mean is supplied the content/structure of input a bit beyond the students' current level. Similarly, an interesting parallel hypothesis is Bruna argued that the children learn a foreign language through scaffolding and routines (cited in Cameron, 2001), CLT suggests that the teacher needs to support comprehensible input to learners (Butler, 2011, p.36-57). A student who does not understand a particular command can observe others for clues that will prepare to respond correctly the next time (Asher, 1972; Asher, 1977).

Krashen (1983) argues that comprehension input is a necessary condition for SLA, but it is not sufficient, if learners with high motivation, sufficient confidence, a good self- image and low anxiety tend to do better in SLA ( p. 66). On the contrary, it is very difficult for learners to acquire L2/foreign language. In short, as mentioned above, it seems that TPR fits well within the principles of SLA. (Richards \& Rodgers, 2001) also argue that learners will soon realize that they understand a lot of things with adequate confidence in TPR's classroom.

2. Psychological foundation

Asher (1981) further notes when a teacher acts a complex utterance as quickly as he/she can, children initially do not say any words, just imitate the teacher' action. In this period, students are internalizing the language what the teacher said just now, which Asher calls this period as Silent Period, after silent period, and then begin to produce the language. TPR is linked with the silence period in psychology, which points out that children should not be forced to output the language immediately and oral practice should be delayed in language classrooms until the learners are ready (Krashen, 1983, p.72; Richards \& Rodgers, 2001).

\section{E. The Features of Young Learners}

The young learner was defined that the aged in the range from 5 to 12 years old. Young learners learn language is different from older learners (McKay, 2012, p.5). Gardner (1993) and Reid (1999, p. 301) confirm that young learners have seven types of intelligence regarding individual differences.

The seven multiple intelligences

1. Linguistic (ability with and sensitivity to words, orally and in writing)

2. Musical (sensitivity to rhythm, pitch and melody)

3. Visual (sensitivity to form, colour, line and shape)

4. Logical mathematical (ability to use numbers effectively and reason well

5. Bodily/kinesthetic (ability to use the body to express ideas and feels)

6. Interpersonal (ability to understand another person's moods and intentions)

7. Intrapersonal (ability to understand yourself, your strengths and weaknesses)

Perceptual learning styles

1. Visual (learns more effectively through the eye (seeing)

2. Auditory (learns more effectively through the ears (hearing)

3. Tactile (learns more effectively through touch (hand-on)

4. Group (learns more effectively through working with others)

5. Global (learns more effectively through concrete experience and interaction with other people)

(Cited in Wedell and Malderez, 2013, p. 163; Gardner, 1993; Reid, 1999, p. 301)

According to the description of the above, there is a strong relationship between the characteristics of young learners and perceptual learning styles. As far as I am concerned, TPR can facilitate young learners' the development of seven types of intelligence. Additionally, one of the things is identified by McKay (2012) that children bring to their language learning their own personalities, likes and dislikes and interests, their own individual cognitive styles and capabilities and their own strengths and weaknesses (p.23). Importantly, the children are full of abundant energy, like skipping, running and stepping by moving their bodies. Applying for TPR with motor actions meets their nature. In a word, TPR does not put the learner under stress, the classroom is so full of activeness, movement, happiness and so on (Mirici, 1999, cited in Er, 2013).

\section{F. TPR Classroom Activities for Young Learners}

Asher (1981) has suggested that TPR activities are conducted mainly based on storytelling, song, games, chant, rhyme and rhythm and so on. He confirms that game is played when one or more players compete or cooperate for pay-offs according to a set of rules (e.g. guessing games or competitive games) (p. 325). Additionally, games provide 
children with opportunities to experience language. TPR songs are implemented by teachers through singing with physical action (e.g. looking, touching, grasping, laughing etc.). Working in groups involves children to use the language in order to negotiate with other peers (Asher, 1981). The tutor takes on the role of the parent, giving prompts, setting patterns. The innovative curriculum clearly reflects an activity based on TPR to encourage teaching and learning through listening, speaking, playing, doing, acting, etc. The aims are to provide a good opportunity for pupils to experience the language and facilitate their own discovery of meaning.

In conclusion, TPR has won popularity since it was introduced to China since the late of 1980s. Gong (2011) makes a comprehensive introduction to refer TPR's the theoretical foundation. Wang (2012) puts forward TPR combined with games, drawing and chants, which can cultivate young learners' positive attitude to learning English (cited in Li, 2016, p.18). TPR emphasizes a positive, collaborative and supportive classroom atmosphere. Children can develop overall's competence including mental and physical. Despite their popularity at home and abroad, but it is also affirmed that faces some of the challenges in practice.

\section{G. The Limitation of TPR}

However, nothing is perfect. TPR also has its drawbacks (AI Harrasi, 2014, p. 40), one drawback is that some teachers may be obliged to follow the curriculum and to finish the task of teaching on time, so the teachers face the challenges of covering all activities within the 40 minutes. Especially, if the course book is full of dense activities, this can make teachers feel rushed and cannot give more attention to children's comprehension. Another drawback is that TPR may be the lack of creativity, because TPR activities are basically based on the imitation of teacher's speech and actions. Thus the pupils are not really trained to produce the novel utterance. For instance, TPR activities are based on a kind of command or requirement refer to listen, sing, match and do, the pupils do not have the opportunity to express their personal viewpoints.

\section{Methodology}

The purpose of this part is to present the qualitative research design for this study, such as the rationale for carrying out the research, participants, instruments as well as the description of the research procedures. In addition, this part will also describe the strategies to collect the data, analyses the data, help to enhance research quality, address some ethical issues and limitations of the present research.

\section{A. Research Aims, Significances and Questions}

The aims are to explore if TPR is regarded as an effective way of teaching children, how the teacher implements TPR in practice and what factors that contribute to the TPR difficulties. It also is to help future teachers to implement TPR technique into their young learner teaching. The results of this study can also help me to reflect on my own teaching approaches. The following three research questions will be addressed.

RQ 1: Is TPR useful in teaching English to young learners? If it is, in what ways will it be effective?

RQ 2: How is TPR used in the classroom?

RQ 3: What challenges are there in using TPR?

\section{B. Qualitative Research}

As Kvale (1996) states that the qualitative research is intended to provide a detailed and rich description and in-depth understanding of an individual's experiences. Thus, the qualitative research interview, observation and document analysis seem to be particularly suitable to investigate teacher experiences curricular implementation and challenges. The integration of methods was conducted through in-depth classroom observation as well as multiple perspectives' interview derived from teachers, parents and students, plus documentary analysis. Mason (2002, p.33-4) advocates the integration of methods for the following reasons:

To explore different elements or parts of a phenomenon, ensuring that the researcher knows how they interrelate.

To answer different research questions.

To answer the same research question, but in different ways and from different perspectives.

To give greater or lesser depth and breadth to analysis.

To triangulate-corroborate-by seeking different data about the same phenomenon. (Cited in Cohen et al., 2011, p. 248)

Therefore, the author believes qualitative approach is suitable for the purpose of her study to help her explore TPR's effectiveness and challenges, enhance the quality of study via triangulate-corroborate from different perspectives. A wide range of research approaches has been created for qualitative approach, such as ethnography, phenomenology, case study, action research (Richards, 2003, p.7). In this study, case study was employed.

\section{Case Study}

A case study in TESOL might focus on a single teacher and perhaps a small group of students in order to provide a detailed description of the unit (Richards, 2003. p. 21). Richards has also mentioned that it would be necessary for the case study to link between an in-depth interviews and classroom observation. Hence, here referred to two teachers' cases: 
Ms Lei - her observation and interview and her student and parent interview

$\mathrm{Mr} \mathrm{Li}$ - his observation and interview and his student and parent interview

\section{Participants}

This study followed the general process of purposeful sampling. Patton (1990) argues that purposeful sampling is effective when a researcher seeks for participants who are likely to give in-depth resources necessary for dealing with research questions. The author decided to select six participants who were involved in this study including two teachers, two students and two parents. Campbell, et al. (2004) argue that many researchers find the informality of unstructured interviewing very suitable to insider' research context when working with colleagues or familiar pupils or clients (p. 101).

Therefore, two teachers who are the author's colleagues, and two students and two parents who are her relatives were invited to take part in this study. One of the reasons is that it is very appropriate for them to be as representative sampling of this study, they're just like what she described in her context (e.g. students belong to left-behind children ). Secondly, they are as her most familiar relatives, their moral character and education background were basically mastered by author. The author believed that they can tell her the real answer via the consistency of their words and actions. Additionally, children could be not feeling timid and scared as the most familiar person around them; they can audaciously express their views without any scruple.

For teachers, through making a call in advance to get their verbal consents, she sent a written consent form to them to confirm their agreement by signature.

For pupils and parents, firstly, the author introduced the purpose of the interview, duration and confidential information to parents in advance. The informed consent was similar to the teachers' interview. After getting their verbal consents, the further interview would be conducted. The interview with children has obtained their parents' permission by orally. The implementation of the study occurred at a private primary school, Guizhou province in China. They are from the same Grade (Grade 5), but in different classes.

\section{FINDINGS}

The author will illustrate the main findings involving her research questions in this part, namely, the effectiveness, application of TPR and the challenges of TPR. The presentation of findings is in accordance with her research instrument, namely, two teachers' cases. Finally, a comparison of findings of two teachers' cases is summarized at the end of this part.

\section{A. Ms Lei's Case}

Ms Lei's teaching procedures were divided into 7 steps. Step 1, she adopted a song as warming up. Learners imitated the teacher' action as well as sang a song. Step 2, she presented some pictures on the blackboard. Firstly, she just demonstrated the motor action and facial expression but not speaking. Then she initially made a command, no physical action, to require students speak words with actions. Step 3, she divided them into 5 groups to have a drill. Step 4, she asked the students to have a role-play, such as I say you do or I do you say. Step 5, she guided students play a guessing-games. Step 6, activities-sing a song was taught with the physical movement. The findings from above have identified that TPR activities were applied the throughout the classroom by TPR songs, games and role-play etc.

In the process of teaching, most of the students were motivated and highly engaged in the classroom, it can be seen that most of students were active, happy and interesting. The combination of observing and doing is sufficient to arouse the enthusiasm of students. I can see the students are very keen on singing, dancing and playing games with the physical movement. It is a harmonious relationship between students and teachers because of all of them always with smiles on their faces. But some students who look less enthusiastic owing to shyness and reticence in role-play, it seems hard for them to open their mouth to speak English with moving their bodies. By observation, it seems to indicate TPR's effectiveness because of arousing the enthusiasm of students, meanwhile, some challenges are clearly revealed in the classroom (e.g. shyness, reticence, students' English proficiency).

Ms Lei is a female, 38 years old, she has received training for teaching English to young learners 3 years ago, with 13 years of teaching experience. She has got the degree of MA-TESOL. When I asked whether she learnt about the TPR, she explained that TPR means the teacher through the motor actions, gestures, etc. to conduct English teaching. She responded her students like TPR activities very much. From the interview I can see that TPR is regarded as an effective way to evoke children's interests. This is consistent with her classroom observation. Probably these findings have indicated potential challenges what TPR faces, because a good opportunity to use English maybe be reduced by excessive mother tongue use. Indeed, noise or discipline problems are also considered as a factor to cause TPR difficulty. TPR were effectively applied to the classroom in primary school. It reflected the characteristics of the CLT/TPR and the requirement of the curriculum.

Child A is Ms Lei's student who lives with her grandparents and sister. Her parents work in Guangzhou. She likes both English class and her English teacher very much, because she can play games in English class. She showed that she spends less time to study English unless the teacher gives a command. She also did not know the significance of learning English. Sometimes her sister helps her to learn English. When I asked whether she uses English outside 
school, she responded: “No, nobody speaks English, I don't dare to speak in public, and I'm worried about making mistakes." According to the interview of Ms Lei' students we can see, games are regarded as a good way to teach young learners. But she seldom touches any English outside of school, she also seems unaware of the significance of learning English and a sense of shyness, probably these factors that contribute to TPR's difficulties.

Parent A is Child A's mother, she said that her child has strong interest in English, she often supervises her children to watch cartoons with English version on TV, and imitating the pronunciations and actions of actors. The expectations for Children's English learning, she announced that there was not any expectation in the primary school stage. As long as she was interested in it and feel happy. The findings indicate the attitude/expectation/supervision for parents toward English education the extent to which have influenced English study of young learners.

\section{B. Mr Li's Case}

Mr Li's class was consisted of lengthy greetings and warming up lasted about 10 minutes, first, he wrote the new words on the blackboard, he taught new words and phrases again and again, then to explain the meaning of the words in Chinese. He stressed the pronunciation of each word. He asked students to remember the vocabulary. 5 minutes was used to introduce grammar structure in Chinese, 5 minutes were used to speak English in terms of mechanical drills. 10 minutes were used to make a dialogue, only 5 minutes were applied to conduct the activities of TPR. He had noticed that there is little time left, so he had to make a summary and arrange the task of after-class.

According to the field notes from $\mathrm{Mr} \mathrm{Li}$, obviously, his class is more used by traditional approaches, because he emphasized on the meaning, pronunciation and memorization of each word, to some extent that have matched the features of GTM/ALM in the previous literature review. Students were required to repeat or remember contents what the teacher commanded. For one-third of the time, Chinese were used. They are passively engaged in the classroom with a little interaction. Part of them feels shy in the process of TPR. From field notes in the above we can see, to some extent, traditional approaches, Children's shyness and time constraint have influenced on the implementation of TPR activities. This shows that the students' English proficiency level is considered as a key factor to impact on teachers' teaching approaches. He stated he did not know about TPR, the reason is that he is a novice and has not engaged in any training regarding TPR. But he often utilizes wards cards to demonstrate by moving his body, eye contact and facial expression.

According to the findings the above, we can conclude that the attitude toward English education for the administrator or parents, teacher and student' English proficiency are regarded as a critical factors that cause TPR difficulties. Child B who is Mr Li's student who lives with her grandmother, her parents work in Fujian, because she hated reciting English words, she also stated that she likes playing games. Nobody helps her to learn English, do not learn English after school, it is not aware of the importance of learning English, my grandmother doesn't know English. The responses of the children are consistent with the description of teachers. According to these descriptions, students like doing games rather than remembering words tediously. Consequently, the attitude towards English or education background for parents has influence on children's English learning.

Parent B who is Child B's mother, nobody concerned about education of child's English, because of with low education level, grandparents are illiteracy. "When we were children, our family was poor; we have just received a little knowledge under primary level. We have no competence to guide my children. Therefore, learning depends on herself. The findings gained from above are in line with teachers' and students' interview, the background of family education and parental expectation and the attitude towards English have also influenced on English learning. While, the children in my context, the parents are kept away from home, the children are the lack of parental supervision and love.

The book used is primary English which concluding 12 lessons with different topics refer to the authentic life of young children, such as school life, sports and food, etc. Each lesson is designed for a variety of activities. Such as let's play, let's chant, let's rhythm, point and say, point and draw, match and sing, etc. The whole learning process is required to learn by doing. Therefore, the textbook matches the features of TPR/young learners. On the contrary, the findings gained from the author assignment module 5994, I can see a set of test papers from the final exam including two major sections: Listening (40 points) and writing (60 points). The total score is 100 points. The result was disclosed that assessing speaking items were zero (Xie, 2017). Although part of them related to listen and draw/ listen and write, but most of them stress memorize things mechanically rather than communicative skill.

\section{DISCUSSION}

In this section, the findings derived from above will be discussed intensively in terms of three research questions, the literature review and the context which have been presented earlier in this study. Through observation, interview, it can be seen, such as different communicative activities designed by Lei and Li, especially in Lei's class, TPR activities were designed to the range from step 1 to step 7, and presented a good effect on students. The findings of the effectiveness of TPR/CLT indicate that 2 teachers share the similar belief which is in line with the features of CLT/TPR. Such as cultivating students' competence, promoting students' interaction. Asher (1972) claimed that TPR activities play an interactive effect between teacher-student and student-student in the authentic classroom. Emphasis on language's experience, this point is consistent with Piaget (1967) and Vygotsky's (1978) views. Evoking students' interests and creating real communication scenario. Child A shared the same notion that they enjoyed the games, songs, 
acting in the classroom. Lei though that she is facilitator and negotiator while students are acted as the state of the imitator and communicator in her class, this viewpoint is in accordance with what I observed, it also fits with the features of TPR/CLT. Krashen (1983) and Ellis (1999) claim that SLA is a subconscious, implicit and informal process. TPR is contacted with the trace theory which implies that more the target language is associated with physical action (Asher, 1984) in the previous part of the theory.

Krashen also indicates the SLA has the relevance with learners' emotion, motivation and self-confidence. Asher (1977) states that TPR could effectively build learners' self-esteem and confidence, when learners respond the commands through the motor movement because students feel secure, do not worry about making mistakes, even though they process low English proficiency (Celestino, 1993). The findings gained from the literature review, classroom observation and interview indicate benefits of TPR as follows: To sum up, according to the teachers, parents and students' interview, Lei have identified TPR as an especially effective method to teach young learners who can successfully foster children' interests via TPR activities with the motor actions. In a ward, in the process of TPR, children learn more effectively through seeing, hearing, hands-on, complete body experience, working with others.

Through the observation and interview, the two teachers developed various tasks refer to the communicative purpose in their classroom, such as singing song, playing games, role-play and pair work in their classes. It can be clearly shown from Ms Lei' class, students were actively involved in TPR activities to develop their communicative competences. The new curriculum also clearly reflects activities based on TPR to encourage teaching and learning through listening, speaking, playing, doing and acting.

It is commonly believed that students' shyness/reticence, English proficiency level, the attitude towards English learning have a significant effect on the implementation of TPR. Children who with extremely low English proficiency as well as different English levels which are presented challenges for teachers to control the degree of the task's difficulty. Additionally, when students are asked to do role-play or pair work, some of the students are reluctant to communicate. The reason of shyness/reticence would be tracked down my context. In my context, the minority of students belong to the left-behind children, the lack of parents' love and supervision. Just as the literature mentioned that students' reticence or low English proficiency is a major obstacle in the process of communication (Ai Harrasi, 2014; Li, 1998; McKay, 2012). Indeed, the findings indicated TPR which has its limitation, perhaps it is more suitable for children who are active and outgoing, for older or introverted children, it could be a big challenge.

Ms Lei shown that the shortage of professional English teacher for children is seen as a secondary factor, for example, the minority of young learner teachers are from the college school for supporting, just as Ms Lei said it is hard for me to switch my role owing to my double status, namely, I teach both adults in my college school and children in this primary school, just like McKay (2012) states that the teaching of young learners are different from adults. Some of them are novices who lack of training refers to young learner English or TPR. Ai Harrasi (2014, p. 39) in his study in Oman has illustrated that TPR may be misapplied by some young learners English teachers, because some teachers may have no idea about the rational principles behind it owing to lack of any training courses related to TPR.

As far as I am concerned, the lack of in-service has seriously influenced on the implementation of the teaching method. It also influenced the English proficiency of students. As the literature mentioned that the traditional approach mainly stresses the translation of second language (Ai Harrasi, 2014, p. 41) and exam-oriented assessment (Hu, 2010; Carless, 2007, p. 597). The challenges of the traditional methods are also about the fact that they are deeply rooted in education (Ai Harrasi, 2014, p.41). Wedell and Malderez (2013) claim that the designs of curriculum, teaching materials and test have influenced teaching method. Through the documentary analysis, even though the curriculum and textbook are entirely followed the features of TPR, while assessment materials are based on exam-oriented in practice. To some extent, exam-oriented have not referred to TPR activities, just as Carless (2007) argues that the contents of assessing have positive or negative impact on what goes on in the classroom and a potential constraint to the implementation of communicative teaching(p.597), the assessment material in this study has a negative effect on teaching. The findings from Mr Li's case, it seems that it is very difficult for teachers to balance the task of teaching and TPT activities (40 minutes). TPR activities are regarded as a waste of time, this is consistent with the literature.

The findings show that the parents are not aware of the significance of English education, leading children to lack of supervision and responsibility to learn English. Their expectations for children are to get higher scores rather than speaking and interests (e.g. parent B's interview). Ms Lei revealed that part of contents in the text book have beyond students' level. In a word, apart from the challenges have mentioned in above, the department of education, parent and children are not aware of the importance of learning English, owing to parent with poor English levels lead to children are lack of supervision, love and cultivation from parents the extent to which cause children conservative traits as a big factor of TPR difficulty.

\section{CONCLUSION}

This paper has addressed all of the author's research questions. The findings of presentation are summarized from two teachers' case studies. Meanwhile, the significance, aims and limitations of this study will be given to the restatement, the aims are to echo the author's introduction. The findings derived from teachers' classroom observation and interview with teachers and students identified that TPR is useful to teaching English to young learners, because it can effectively arouse students' enthusiasm, evoke students' interests, reduce affective filter, enhance motivation and 
build up confidence to learn English. Meanwhile, it also can be proved that it has benefits in the aspects of students' listening and imperative sentences etc. Most importantly, it can clearly reflect the features of young learner, and match the requirement of the curriculum for primary English. From the findings of two teachers' observation and interview, we can see that TPR is mainly depending on students listening to a command and then immediately responding with the appropriate physical action, gesture, eyesight and facial expression via TPR songs, TPR games and pair work and so on.

Most importantly, this study identified TPR's challenges in the author's context, for instance, the factor derived from teachers, students and parents (e.g. the use of traditional method, students' English proficiency, the lack of training, the lack of supervision and so on). However, it has been proved that curriculum and course books are consistent with the features of TPR, while the exam-oriented system is identified as a significant factor to cause TPR's challenges. Actually, TPR technique also revealed its drawbacks (e.g. it is not suitable to teach grammar and introverted students). There is a bit limitation that the author has to acknowledge here. The research was conducted with a small number of participants with one-shot interview within a limited time, which may not obtain as much information as the author expected.

All in all, through a systemic introduction of TPR in this study, more teachers will know about it and may apply it in the future. The results of this study can also help the author to reflect on her own teaching approaches and support other teachers working in her school. It is useful to improve young learners' English teaching, especially in the author own local context. Since there is a push in China and in her province to more English for young learners and at even earlier ages to learn English, it hopes that this study will add some small insights into ways of improving teaching English to young learners. As this study progressed, studying TPR on a large scale field in primary school arouse her great interest as she deepens understanding of TPR.

\section{ACKNOWLEDGMENTS}

The research is financed by the department of education planning project in Guizhou province. Project No.: 2018 A002. Important project. The title of the project "The Effectiveness of Total Physical Response (TPR) on Teaching English to Young Learners". Thanks for Prof. Martin who gave me so much valuable suggestions about the article. In addition, I'm grateful to my families who supported enough time and energies for me to write this paper. Many thanks to them.

\section{REFERENCES}

[1] Asher, J. J. (1972). Children's first language as a model for second language learning. Modern Language Journal, 56(3), 133-139.

[2] Asher, J. J. (1977). Learning another language through actions: the complete teacher's guidebook (vol. 1). Adult Education, 127-129.

[3] Asher, J. J. (1981). The Total Physical Response: Theory and Practice. Annals of the New York Academy of Sciences, December Vol.379 (1), pp.324-331

[4] Al Harrasi, K. T. S. (2014). Using "total physical response" with young learners in Oman. Childhood Education, 90(1), 36-42.

[5] Bulter, Y. G. (2004). What Level of English Proficiency Do Elementary School Teachers Need to Attain to Teach EFL? Case Studies from Korea, Taiwan, and Japan. TESOL Quarterly, 38, 245-278. Doi: 10.2307/3588380.

[6] Baker, W. (2008). A critical examination of ELT in Thailand: the role of cultural awareness. Relc Journal, 39(1), 131-146.

[7] Butler, Y. G. (2011). The implementation of communicative and task-based language teaching in the Asia-pacific region. Annual Review of Applied Linguistics, 31(31), 36-57.

[8] Borg, S. (2011). The impact of in-service teacher education on language teachers' beliefs. System, 39(3), 370-380.

[9] Borg, S. (2012). Doing good quality research. ELT. Research. Spring. Issue 26, 53-55.

[10] Celestino, W. J. (1993). Total physical response: commands not control. Hispania, 76 (4), 902-903.

[11] Cameron, L. (2001). Teaching languages to young learners. Cambridge, UK: Cambridge University Press.

[12] Carless, D. R. (2003). Factors in the implementation of task-based teaching in primary schools. System, 31(4), 485-500.

[13] Campbell, A., McNamara, O., and Glny, P. (2004). Practitioner research and professional development introduction. London: Paul Chapman.

[14] Carless, D. R. (2007). The suitability of task-based approaches for secondary schools: Perspectives from Hong Kong. System, 35(2007), 595-608.

[15] Cohen, L., Manion, L., \& Morrison, K. (2011). Research Methods in Education. London: The Taylor \& Francis Group, Routledge.

[16] Diane \& Larsen-Freeman. (2000). Total physical response. Basic education research of foreign language teaching 61(1), 28-35.

[17] Ellis R. (1999). Understanding Second Language Acquisition. Shanghai: Shanghai Foreign Language Education Press. p42.

[18] Er, S. (2013). Using total physical response method in early childhood foreign language teaching environments. Procedia-Social and Behavioural Sciences, 93(1), 1766-1768.

[19] Gardner, H. (1993). Multiple intelligences: the theory in practice. A reader, 32(6), 304-306.

[20] Garton, S., Copland, F., \& Burns, A. (2011). Investigating global practices in teaching English to young learners. British Council ELT.

[21] Gong, X. (2011). The application of Total Physical Response (TPR) in children's English Teaching. Doctoral dissertation, Central China Normal University, China.

[22] Hu, G. (2002). Potential cultural resistance to pedagogical imports: the case of communicative language teaching in China. Language Culture \& Curriculum, 15(2), 93-105. 
[23] Hu, Y. Y. (2008). China's English language policy for primary schools. World English, 27(3-4), 516-534.

[24] Krashen .D. (1983). Principles and practice in second language. Oxford: Pergamon.

[25] Kvale, S. \& Brinkmann, S., Interviews learning the craft of qualitative research interviewing. London: Sage. p.123-142.

[26] Li, D. (1998). It's always more difficult than you plan and imagine: teachers' perceived difficulties in introducing the communicative approach in South Korea. Tesol Quarterly, 32(4), 677-703.

[27] Littlewood, W. (2007). Communicative and task-based teaching in east Asian classrooms. Language Teaching, 40(3), $243-249$.

[28] Li, Y. (2016). Study on Application of TPR in English Teaching in Primary School. Doctoral dissertation, Yanbian University, China.

[29] Moon, J. (2005). Teaching English to Young Learners: the challenges and the benefits. In English (vol. 34). British Council, 30-33.

[30] Ministry of Education of P. R. C. (2011). Compulsory education English Curriculum Standard, China: Beijing Normal University Press, pp.1-23.

[31] McKay. P. (2012). Assessing young language learners. UK: Cambridge University Press.

[32] Patton, M. Q. (1990). Qualitative evaluation and research methods (2nd Ed.)... Qualitative evaluation and research methods. USA: Sage Publications.

[33] Porta, Inés Jiménez. (2013). The use of TPR games to learn English vocabulary in Infant, Universitat De Vic. Facultat D'Educació, Traducció I Ciències Humanes, Vic, 17 de maig de.

[34] Richards, J.C. \& Rodgers, T.S. (2001). Approaches and methods in language teaching. Cambridge: Cambridge University press.

[35] Richards, K. (2003). Qualitative Inquiry in TESOL. Palgrave Macmillan UK.

[36] Savignon, S. J. (2003). Teaching English as communication: a global perspective. World English, 22(1), 55-66.

[37] Shaaban, K. (2005). Assessment of young learners. Forum, 39, N/A.

[38] Wang, Q. (2002). Primary school English teaching in china. New Developments. Vol. 7, 99-108

[39] Wedell, M., \& Malderez, A. (2013). Understanding language classroom contexts: the starting point for change. Oxford University Press.

[40] Xie, R. \& Ding, D. S. (2017). The Influence of Local Context on the Games in Teaching English to Young Learners (TEYL) in Tongren (China). International Journal of Education. Macrothink. DOI: https://doi.org/10.5296/ije.v9i2.10998.

[41] Xie, R. (2017). Why Do Young EFL Learners Find Speaking Difficulties? Unpublished postgraduate assignment, University of Leeds.

[42] Xie, R. (2017). Investigating the Content Validity of the Junior Middle School Entrance English Testing. Unpublished postgraduate assignment, University of Leeds.

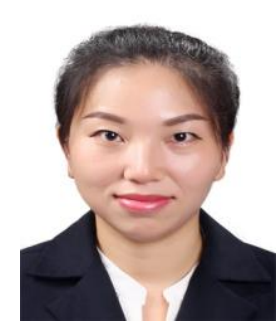

Rong Xie is an Associate Professor in TESOL BA program of Tongren Preschool Education College, Tongren, Guizhou, China. She got her MA TESOL from University of Leeds in 2017. Her research interests include English teaching, young learner English teaching and pedagogy. 